\title{
B-cell-specific Moloney murine leukemia virus integration site I: potential stratification factor and therapeutic target for epithelial ovarian cancer [Corrigendum]
}

\author{
Zhao Q, Gui T, Qian Q, Li L, Shen K. OncoTargets and \\ Therapy. 2016;9:5203-5208.
}

On page 5207, right column, the Acknowledgement section was not included. It should have been:

\section{Acknowledgments}

This study was supported by the National Natural Science Foundation of China (No 81402140 and No 81372780).
OncoTargets and Therapy

\section{Publish your work in this journal}

OncoTargets and Therapy is an international, peer-reviewed, open access journal focusing on the pathological basis of all cancers, potential targets for therapy and treatment protocols employed to improve the management of cancer patients. The journal also focuses on the impact of management programs and new therapeutic agents and protocols on

\section{Dovepress}

patient perspectives such as quality of life, adherence and satisfaction. The manuscript management system is completely online and includes a very quick and fair peer-review system, which is all easy to use. Visit http://www.dovepress.com/testimonials.php to read real quotes from published authors 